Sains Malaysiana 49(6)(2020): 1283-1292

http://dx.doi.org/10.17576/jsm-2020-4906-06

\title{
Effect of Ethanol and Methanol on the Total Phenolic Content and Antioxidant Capacity of Chia Seeds (Salvia hispanica L.)
}

(Kesan Etanol dan Metanol ke atas Jumlah Kandungan Fenolik dan Kemampuan Antioksidan dalam Biji Chia (Salvia hispanica L.))

\author{
Morales-OlÁn Gema, Rojas-López MARLon, DíAZ-Reyes Joel, Rosas-CÁRdenAs Flor De FÁtima \& LUNA- \\ SUÁREZ SILVIA*
}

\section{ABSTRACT}

The use of methanol and ethanol for the extraction of antioxidant compounds in Chia Seed (Salvia hispanica L.) is studied, but only the effect of a single concentration of these solvents was evaluated. However, factors such as the nature and the concentration of the solvents determines the content of phenolic compounds, the antioxidant capacity and the possible use of the extract. For this reason, it is necessary to have a detailed study of different extraction conditions to find the optimum. The objective of this work was to evaluate the effect of different concentrations of ethanol and methanol and the hexane treatment on the extraction of phenolic compounds and the antioxidant capacity of the Chia Seeds extracts. The greatest total phenolic content was obtained in the 50\% aqueous ethanol and methanol extracts. Nevertheless, all the extracts showed a high DPPH scavenging activity. With exception of 100\% ethanol extract, no significant differences were found between the extracts treated with and without hexane. No significant differences were found in the extraction yields of the $80 \%$ aqueous ethanol and methanol extracts, but the aqueous methanol extract presented lower IC $C_{50}$. The FTIR and UV-VIS spectra of the aqueous ethanol and methanol Chia extracts suggest differences in the composition of the extracts. It is possible to extract the phenolic compounds from the Chia Seeds with different concentration of ethanol and methanol, which will allow to select the appropriate extraction conditions according to the application of the extract.

Keywords: Antioxidants; Chia Seeds; hexane treatment; phenolic compound; solvent extraction

ABSTRAK

Penggunaan metanol dan etanol untuk pengekstrakan sebatian antioksidan dalam Biji Chia (Salvia hispanica L.) telah dikaji, tetapi hanya kesan satu kepekatan pelarut telah dinilai. Faktor seperti sifat dan kepekatan pelarut menentukan kandungan sebatian fenolik, keupayaan pengantioksidan ekstrak serta kegunaan ekstrak. Oleh itu, kajian terperinci tentang keadaan pengekstrakan yang berbeza diperlukan untuk mendapatkan nilai yang optimum. Objektif kajian ini adalah untuk menilai kesan kepekatan etanol dan metanol yang berbeza dan rawatan heksana terhadap pengekstrakan sebatian fenolik dan keupayaan antioksidan ekstrak Biji Chia. Kandungan fenolik terbesar diekstrak menggunakan 50\% larutan etanol dan metanol. Walau bagaimanapun, semua ekstrak menunjukkan aktiviti hapus sisa DPPH yang tinggi. Kecuali ekstrak etanol 100\%, tiada perbezaan yang ketara dijumpai antara ekstrak-ekstrak yang dirawat dengan heksana dan tanpa heksana. Tidak terdapat perbezaan yang ketara dalam hasil pengekstrakan $80 \%$ etanol dengan ekstrak metanol, tetapi ekstrak larutan metanol menunjukkan IC ${ }_{50}$ yang lebih rendah. Spektrum FTIR dan UV-VIS daripada ekstrak larutan etanol dan ekstrak metanol Biji Chia menunjukkan perbezaan dalam komposisi ekstrak. Sebatian fenol boleh diekstrak daripada Biji Chia dengan kepekatan etanol dan metanol yang berbeza, yang boleh menentukan kegunaan ekstrak mengikut kesesuaiannya.

Kata kunci: Biji Chia; pengantioksidan; pengekstrakan pelarut; rawatan heksana; sebatian fenol

\section{INTRODUCTION}

Chia Seeds (Salvia hispanica L.) have acquired great value for society due to their nutritional and medicinal properties. As a food, they contribute a significant amount of proteins $(15-25 \%)$, carbohydrates $(26-41 \%)$, fatty acids (30-33\%) and fibre (18-30\%) (Ixtaina et al. 2008).
In medicine, has been described that they protect against degenerative diseases such as atherosclerosis, cancer, Alzheimer's and Parkinson's (Corona et al. 2016; Valdivia $\&$ Tecante 2015). These properties are attributed to the phenolic compounds with potential antioxidant activity that they contain, such as the myricetin, quercetin, and kaempferol (Capitani et al. 2012; Reyes et al. 2008). The 
total phenolic content reported in Chia Seeds range from 0.64 to $1.63 \mathrm{mg} \mathrm{GAE} / \mathrm{g}$ in $100 \%$ ethanol and $70 \%$ aqueous methanol extracts (Capitani et al. 2014; Martínez-Cruz \& Paredes-López 2014; Silveira \& Salas 2014). The phenolic content in Chia Seed is higher than in other plant species (Kähkönen et al. 1999). Antioxidants are also used as additives in food preservation and, due to the importance of these molecules, many investigations seek methodologies that allow their extraction with high yields. One of the techniques widely used is the extraction with solvents, such as water, ethanol, methanol, hexane among others (Santos \& Gonçalves, 2016). However, the nature of the solvent, their concentration and the time of exposure, are factors that affect the efficiency of the extraction of the phenolic compounds (Azmir et al. 2013). And they delimit the application of the extracts, there are restrictions on the use of certain solvents, due to their toxicity according to different legislations. In Chia Seeds, it is not possible to use only water for the extraction of phenolic compound. When the seed is mixed with the water, releases a tetra saccharide called mucilage (Muñoz et al. 2012). The mucilage retains water and forms a highly viscous solution that avoids the extraction of phenolic compounds. For this reason, it is necessary to use other polar solvents and their mixtures with water. Methanol is known as an efficient agent for its extraction (Do et al. 2014) but it is toxic (Villanueva et al. 2002). On the other hand, ethanol represents a safe solvent alternative in separation processes of compounds for human consume (Ignat et al. 2011). In some methods, it is proposed that before the extraction of phenolic compounds, the lipids are removed from the samples or washed the extracts with hexane, in order to obtain purer extracts and quantify a higher content of phenolic compounds (Silveira \& Salas 2014). However, the use of another solvent, makes the process more expensive and limits the application of the isolate because hexane is considered toxic (Buddrick et al. 2013). The objective of this work was to evaluate the effect of different concentrations of ethanol and methanol and the hexane treatment on the extraction of phenolic compounds and the antioxidant capacity of the Chia Seeds extracts. Likewise, techniques such as UV-Visible and FTIR were applied to analyse the extracts. This study will establish the adequate conditions for the extraction of antioxidant compounds from the Chia Seeds and their potential applications.

\section{MATERIALS AND METHODS}

\section{SEEDS AND REAGENTS}

Chia Seed was purchased from a local market in Puebla City, Mexico. They were cleaned manually and were passed through a 20 -mesh screen. The flour was generated by grinding the seeds in a food processor and passing them through a 35-mesh screen. The flour was stored at $4{ }^{\circ} \mathrm{C}$ until its use. The 2,2-diphenyl-1-picrylhydrazil (DPPH), Folin-Ciocalteu reagent, Gallic acid and standards HPLC grade (Quercetin $\geq 95 \%$, Kaempferol $\geq$ $90 \%$, Myricetin $\geq 96.0 \%$, Caffeic acid $\geq 98.0 \%$, Transcinnamic acid $\geq 99.0 \%$ ) were obtained from Sigma Aldrich (Sigma Co., San Luis, U.S.A.).

\section{EXTRACTION AND DETERMINATION OF TOTAL PHENOL CONTENT}

The phenolic compounds were extracted using the methods proposed by Martínez-Cruz and Paredes-López (2014). $0.5 \mathrm{~g}$ of chia flour was mixed with $3 \mathrm{~mL}$ of different concentrations $(50,60,70,80,90 \%)$ of ethanol and methanol in water and $100 \%$ ethanol and methanol, respectively. The samples were kept under agitation for $24 \mathrm{~h}$ at $25^{\circ} \mathrm{C}$ and were centrifuged at $6,000 \mathrm{rpm}$ for $10 \mathrm{~min}$. For hexane treatment of the extracts: 3 $\mathrm{mL}$ of hexane was added to the ethanol and methanol extracts, stirred for $5 \mathrm{~min}$ at $25^{\circ} \mathrm{C}$ and the phases were separated with a separatory funnel. This procedure was performed three times. The extracts were stored at 10 ${ }^{\circ} \mathrm{C}$ until analysis. A completely randomized design was carried out with a $2 \times 2 \times 6$ factorial arrangements. The quantification of total phenolic content was determined using the Folin-Ciocalteu method (Swain \& Hillis 1959) in microplate. The gallic acid was used as standard in the calibration curve, the results were expressed in milligrams equivalents of gallic acid per gram of Chia Seed (mg GAE/g of Chia Seed). The results show the mean of three replicates \pm standard deviation (SD).

\section{DPPH RADICAL SCAVENGING ACTIVITY}

The antioxidant capacity of the extracts was determined by DPPH assay (Corral et al. 2008) in microplate. 280 $\mu \mathrm{L}$ of the $100 \mathrm{mM}$ DPPH solution was mixed with 20 $\mu \mathrm{L}$ of each of the extracts. The percentage of the DPPH scavenging activity was determined using (1):

DPPH scavenging activity $(\%)=$

$$
\frac{\text { Absorbance }_{\text {control }}-\text { Absorbance }_{\text {sample }}}{\text { Absorbance }_{\text {control }}} \times 100 \%
$$

The results show the mean of three replicates \pm SD.

$$
\mathrm{IC}_{50} \text { AND EXTRACTION YIELD }
$$

The alcohol of extracts was removed by rotary evaporator and the water by lyophilisation. From the lyophilised, solutions were prepared with a concentration of $1-10 \mathrm{mg}$ / $\mathrm{mL}$ in water. The half-maximal inhibitory concentration $\left(\mathrm{IC}_{50}\right)$ was reported as the amount of antioxidant required 
to decrease the initial DPPH concentration by $50 \%$. The extraction yield was calculated considering the initial grams of seeds, from (2):

Extraction yield $(\%)=\mathrm{g}$ of extract $/ \mathrm{g}$ of seeds $\times 100 \%$

\section{SPECTRAL SCANNING BY UV-VISIBLE AND STRUCTURAL ANALYSIS BY FTIR}

The $80 \%$ aqueous ethanol and methanol extracts without and with hexane treatment and the standards were dissolved in water. The UV-Visible scan was performed in the wavelength range of $200-900 \mathrm{~nm}$. The lyophilized extracts were characterized with a FTIR spectrometer (Bruker Vertex 70, Germany) equipped with a total attenuated reflectance (ATR) accessory. The spectral measurements were recorded in the wavenumber range between $4000-500 \mathrm{~cm}^{-1}$.

\section{STATISTICAL ANALYSIS}

Analysis of variance (ANOVA) and Tukey tests were performed using the Minitab 16.0 program (Minitab, Inc., State College, PA, USA). The significant differences between the values of the means for each treatment were calculated with a probability of $P<0.05$.

\section{RESULTS AND DISCUSSION}

\section{TOTAL PHENOLIC CONTENT}

Figure 1 shows the total phenolic content of the extracts obtained from the calibration curve with gallic acid (0$\left.100 \mu \mathrm{g} / \mathrm{mL}, \mathrm{y}=0.0017 \mathrm{x}+0.0519, \mathrm{R}^{2}=0.99\right)$. In both series of ethanol and methanol extracts a similar trend was obtained. As the alcohol concentration decreases and

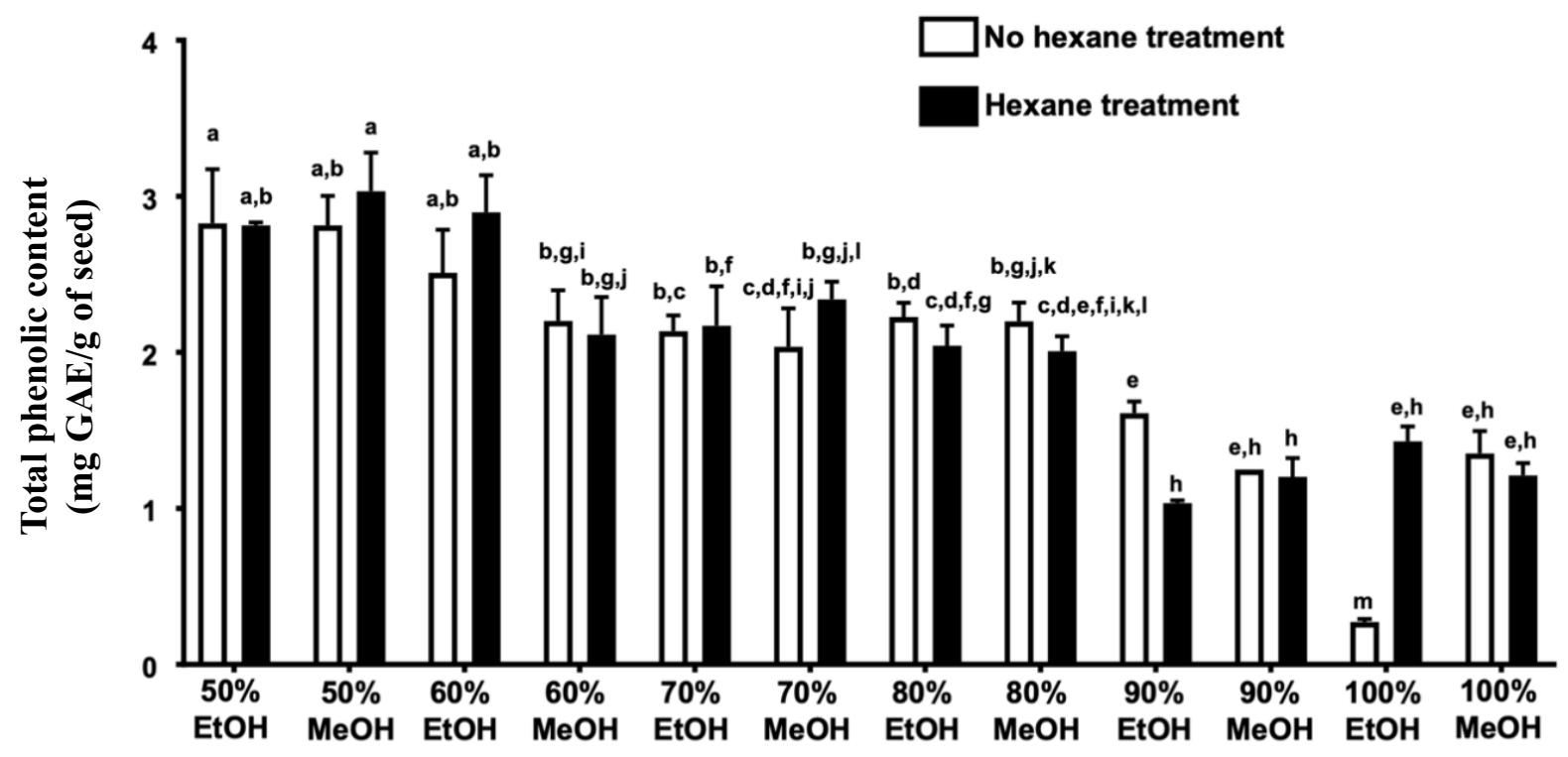

Extracts

FIGURE 1. Total phenolic content of ethanol (EtOH) and methanol (MeOH) extracts of Salvia hispanica L. seeds with and without hexane treatment. Columns with different letter are statistically different according to the Tukey test $(P<0.05)$

the content of water increases, the content of phenolic compounds increases. Concentrations $<50 \%$ were not considered because the release of the mucilage from the Chia Seed is favoured. The mucilage retains water and generates a viscous solution that does not permit the extraction of phenolic compounds.

The highest phenolic content in the ethanol extracts without and with treatment was quantified in the 50 and 
$60 \%$ aqueous ethanol extracts. However, no significant differences were found between the total phenolic content in the 60,70 , and $80 \%$ extracts. The lowest phenolic content was obtained in the 90 , and $100 \%$ ethanol extracts. On the other hand, with exception of $100 \%$ ethanol extract, no significant differences were found between the phenolic content of the ethanol extracts without and with hexane treatment. After hexane treatment, in the $100 \%$ ethanol extract a greater content of compounds was quantified. This may suggest that compounds of different nature such as terpenes, saponins and others may be extracted with $100 \%$ ethanol. These molecules can interact with the phenols forming complex structures that interfere with the quantification of the total phenols content (Do et al. 2014). The results demonstrate that, hexane washes could eliminate these compounds from the extracts, so that after treatment a greater content of phenols is quantified.

The total phenolic compounds extracted with the aqueous ethanol solutions was higher than that reported in the literature. Reyes et al. (2008) quantified $0.88 \mathrm{mg}$ $\mathrm{GAE} / \mathrm{g}$ of chia in the $100 \%$ ethanol extract obtained from the mixture of the defatted flour with the solvent in relation 1:10, under stirring for $48 \mathrm{~h}$. Marineli et al. (2014) with the same conditions reported $0.94 \pm 0.0 \mathrm{mg}$ $\mathrm{GAE} / \mathrm{g}$ of Chia. In this study, in the $100 \%$ ethanol extract generated by mixing the flour with ethanol in relation 1:6 and treated with hexane, $36 \%$ more phenolic compounds were extracted. The highest phenolic content in methanol extracts without and with hexane treatment was obtained in the $50 \%$ aqueous methanol extract. No significant differences were found between 60,70 , and $80 \%$ aqueous methanol extracts. And as in ethanol extracts, the lowest concentration of phenols was quantified in the $90 \%$, and $100 \%$ methanol extracts. Hexane treatment did not had effect on the content of phenolic compounds in the methanol extracts. No significant differences were found between methanol extracts without and with treatment. The total phenolic content extracted with $100 \%$ methanol was $50 \%$ more than that reported by Silveira and Salas (2014). They reported $0.64 \mathrm{mg}$ GAE/g of chia in the $100 \%$ methanol extract obtained of mixing the flour with the solvent in a ratio of 1:8 and treated with hexane. No significant differences were found between total phenolic content reported by Martínez-Cruz and Paredes-López (2014) in the $70 \%$ aqueous methanol extract without hexane washes and the obtained in this investigation under the same conditions. Among the ethanol and methanol extracts without hexane treatment, significant differences were found in the total phenolic content of the $100 \%$ ethanol extracts. The phenolic compounds in the $100 \%$ methanol extract was significantly higher than that of the $100 \%$ ethanol extract. Finally, there were no significant differences between ethanol and methanol extracts treated with hexane. It has been reported that the extraction of phenolic compounds is more efficient with methanol (Castañeda et al. 2009; Ignat et al. 2011) and in this research similar results were obtained between ethanol and methanol when mixed with water; however, $100 \%$ methanol extracted higher amount than 100\% ethanol (Figure 1). In this study, it was observed that as water concentration increase, the amount of phenolic content increase, and the behaviour in both alcohols is the same. This indicate that the water favours the extraction of the phenolic compounds in Chia Seeds. The solubility of antioxidant compounds in a solvent depends on the characteristics of the phytochemicals present in the food (Santos \& Gonçalves 2016). The phenolic compounds of chia are polar, so they could be extracted easily with water. However, the aqueous extraction in Chia Seeds is not possible due to the release of mucilage.

\section{DPPH RADICAL SCAVENGING ACTIVITY}

Figure 2 shows the DPPH scavenging activity of the extracts with and without hexane treatment. With exception of $100 \%$ ethanol extract without treatment, the extracts gave a high DPPH radical scavenging activity $(>80 \%)$. Statistically only significant differences were found in antioxidant capacity of the $100 \%$ ethanol extract without hexane treatment. This extract presented a lower radical scavenging capacity and total phenolic content. The treatment with hexane influenced on the antioxidant capacity of the $100 \%$ ethanol extract, which allowed that the activity increase. This may be attributable to the fact that hexane treatment can eliminate compounds of different nature that interfere with the antioxidant activity of phenolic compounds.

No significant difference was found between the DPPH radical scavenging activity of the methanol extracts hexane treated and not treated. Similarly, no significant difference was found between the antioxidant capacity of the $50-90 \%$ aqueous ethanol and methanol extracts hexane treated and not treated. There are no reports of the DPPH scavenging activities of the ethanol extracts to compare these results. Martínez-Cruz and Paredes-López (2014) in the 70\% aqueous methanol extract of Chia Seeds reported an inhibition of DPPH of $68.8 \%$. In this study, the DPPH radical scavenging activity of the extract obtained with the same concentration and conditions was higher $(85.1 \pm 1.6 \%)$. Silveira and Salas (2014) reported a 50\% reduction of the DPPH radical with the extract generated with $100 \%$ methanol. However, in this work, a greater DPPH radical scavenging activity was found $(88.2 \pm 1.3 \%)$ in the extracts with the 
same concentration of the methanol. The DPPH radical scavenging activity of the Lamiaceae family has already been described in species such as Salvia officinalis (92.3 $\pm 0.5 \%)$, Salvia sclarea (92.9 $\pm 0.4 \%)$, Salvia glutinosa $(91.5 \pm 0.5 \%)$ and Salvia pratensis $(93.0 \pm 0.5 \% \mathrm{IDPPH})$ (Miliauskas et al. 2004).

A correlation analysis was performed between total phenol content and the DPPH radical scavenging activity of the extracts. The ethanol extracts with and without hexane treatment presented a positive relationship and mean correlation of $\mathrm{R}^{2}=0.67 \pm 0.07$ and $\mathrm{R}^{2}=0.67 \pm 0.12$, respectively. The correlation in methanol extracts with and without hexane were lower than in ethanol extracts, $\mathrm{R}^{2}=0.40 \pm 0.2$, and $\mathrm{R}^{2}=0.53 \pm 0.10$. However, these correlations were not statistically different according to the Tukey test $(P<0.05)$. Some investigations found a strong correlation between the total content of phenolic compounds and the DPPH radical scavenging activity (Repo-De-Carrasco \& Encina-Zelada 2008). However, other authors explain that these correlations are not completely linear, since it has been observed that the aqueous organic extracts may contain other non-antioxidant food constituents that may interfere in the assays of the antioxidant capacity and quantification of phenolic compounds, such as vitamins and minerals (MacDonald-Wicks et al. 2006; Santos \& Gonçalves 2016).

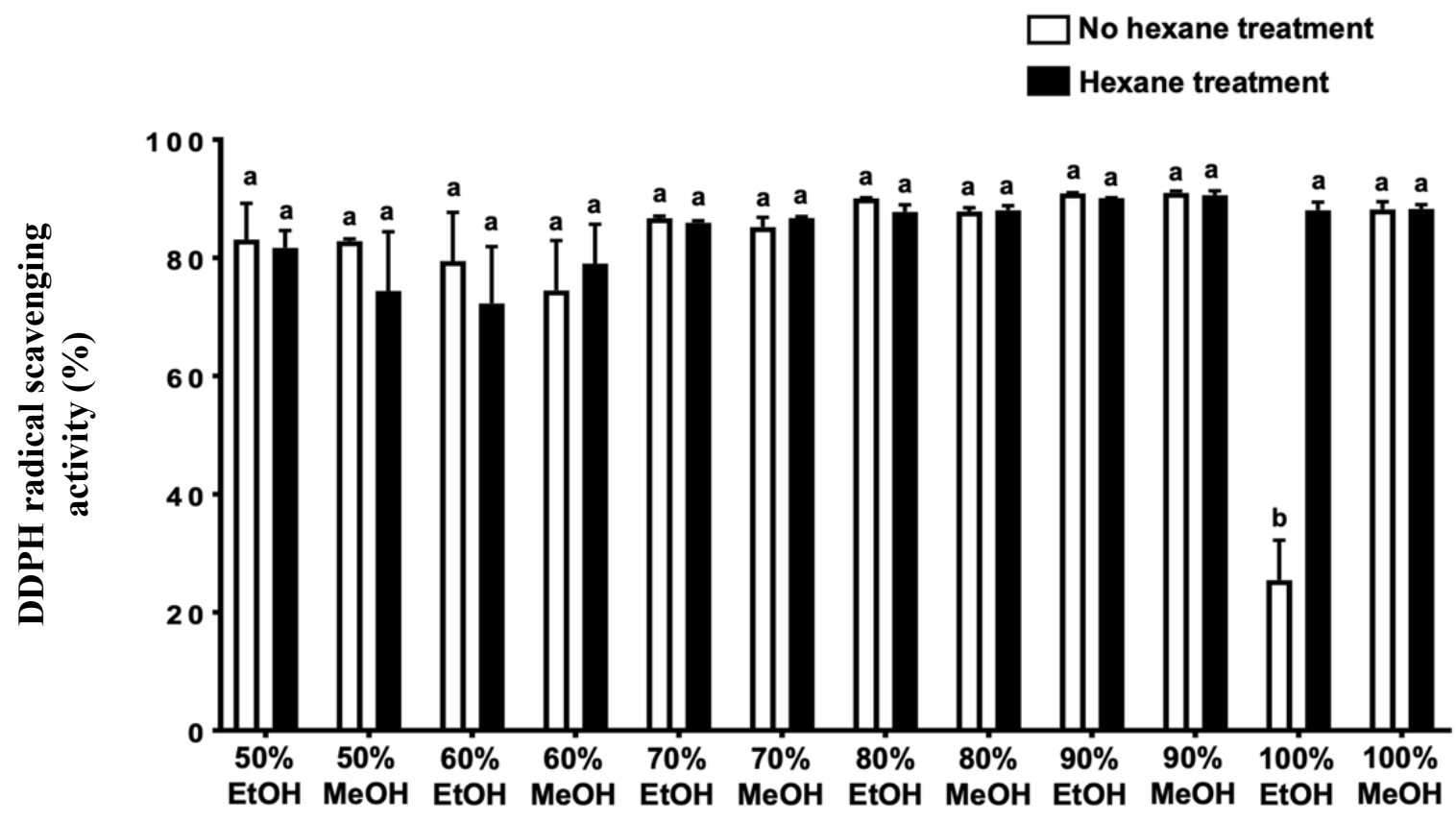

Extracts

FIGURE 2. DPPH radical scavenging activity of ethanol (EtOH) and methanol (MeOH) extracts of Salvia hispanica L. seeds with and without hexane treatment. Columns with different letter are statistically different according to the Tukey test $(P<0.05)$

\section{$\mathrm{IC}_{50}$ AND EXTRACTION YIELDS}

Table 1 shows the $\mathrm{IC}_{50}$ of the $80 \%$ aqueous alcohol extracts and their extraction yields. These samples were selected because they showed a high DPPH radical scavenging activity and water solubility. The extracts were redissolved in water because the main application of antioxidant plant extracts is in the food manufacturing. 
This industry restricts the use of certain solvents due to their toxicity. In addition, preliminary solubility tests were performed to choose the solvent. The extracts were re-dissolved in water and in the respective alcohols and the content of phenolic compounds in the solutions was quantified. In these tests, no significant differences were found between the samples.

TABLE $1 . \mathrm{IC}_{50}$ and extraction yield of the $80 \%$ aqueous ethanol and methanol extracts of the Salvia hispanica L. seeds

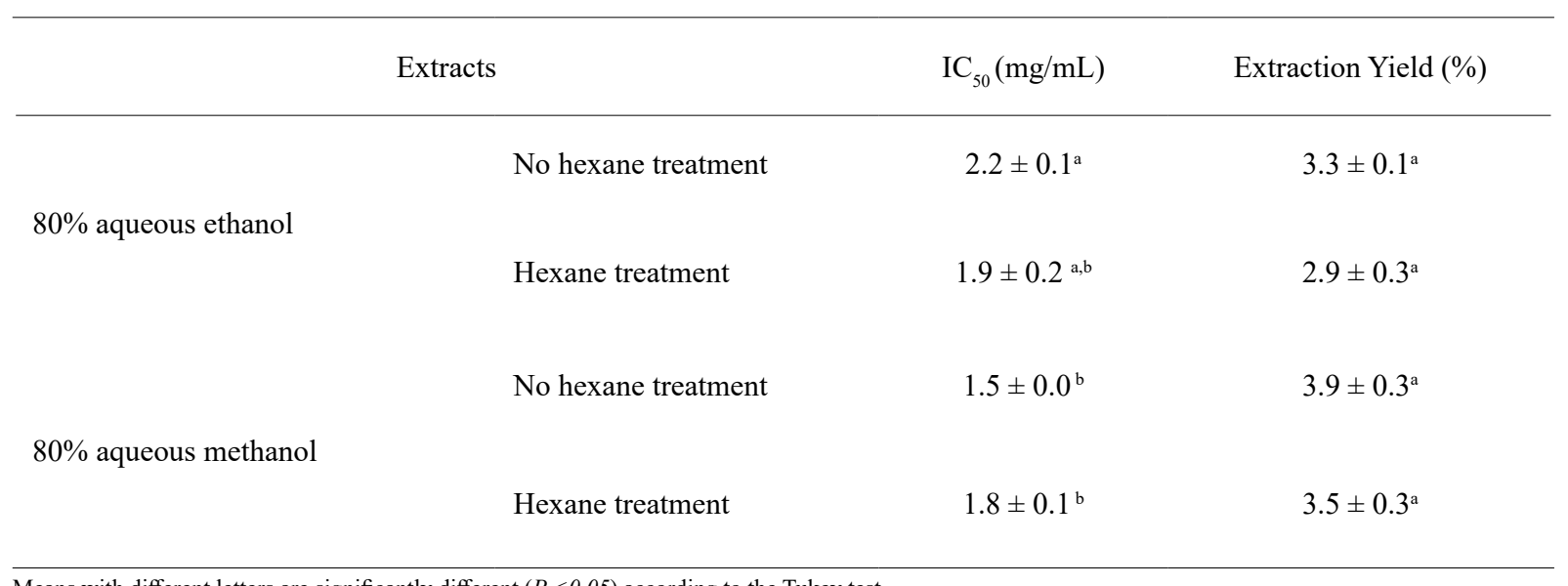

Means with different letters are significantly different $(P<0.05)$ according to the Tukey test

The $\mathrm{IC}_{50}$ of the $80 \%$ aqueous ethanol and methanol extracts were better than reported by Scapin et al. (2016) $\left(\mathrm{IC}_{50}=3.8 \pm 0.1 \mathrm{mg} / \mathrm{mL}\right)$. They evaluated the antioxidant activity of the $80 \%$ aqueous ethanol extracts of Chia Seeds obtained under heating conditions $\left(40^{\circ} \mathrm{C}\right)$. Chia isolates have higher antioxidant capacity than mint (Mentha arvensis) $\left(\mathrm{IC}_{50}=17.4 \mathrm{mg} / \mathrm{mL}\right)$ (De Morais et al. 2009), Star fruit (Averrhoa carambola) $\left(\mathrm{IC}_{50}=3.8 \pm 2.1\right.$ $\mathrm{mg} / \mathrm{mL}$ ) (Lim et al. 2006) and Brazilian berry (Myrciaria jaboticaba) $\left(\mathrm{IC}_{50}=3.54 \mathrm{mg} / \mathrm{mL}\right)$ (Da Silva et al. 2017). No significant differences were found between the $\mathrm{IC}_{50}$ of extracts with and without hexane treatment. However, there are differences between the $\mathrm{IC}_{50}$ of $80 \%$ aqueous ethanol and methanol extracts without hexane treatment. Among these, $80 \%$ aqueous ethanol extracts have a lower antioxidant capacity. In the literature there are no reports of the extraction yields of ethanol and methanol extracts in Chia Seed. The results obtained are similar to those reported in alcohol extracts of other seeds, such as Hordeum vulgare L. and Hibiscus cannabinus L. (Anwar et al. 2010; Yusri et al. 2012). Some authors describe that the extraction yields are dependent on the solvent used
(Goli et al. 2004; Stalikas 2007) but in this investigation no significant differences were found between the aqueous ethanol and methanol extracts yields.

\section{SPECTRAL SCANNING BY UV-VISIBLE AND STRUCTURAL ANALYSIS BY FTIR}

Figure 3 shows the UV-Visible spectral scanning of the $80 \%$ aqueous ethanol and methanol extracts and standards in the wavelength range of 200-500 nm. From $500 \mathrm{~nm}$ no absorbance of the samples was observed. In aqueous alcohol extracts of Chia Seed, flavonoid compounds such as myricetin, quercetin and kaempferol have been identified, as well as phenolic acids (chlorogenic, caffeic, and cinnamic) (Capitani et al. 2014; Marineli et al. 2014; Martínez-Cruz \& Paredes-López 2014; Silveira \& Salas 2014). The absorbance profile observed in $80 \%$ aqueous ethanol and methanol extracts of chia is compatible with flavonoids. These molecules present a maximum absorbance between 240-290 $\mathrm{nm}$ due to the absorption of A ring and another maximum greater than $300 \mathrm{~nm}$ depending of the substitutions and conjugations of the $\mathrm{C}$ ring (Zhao et al. 2006). 


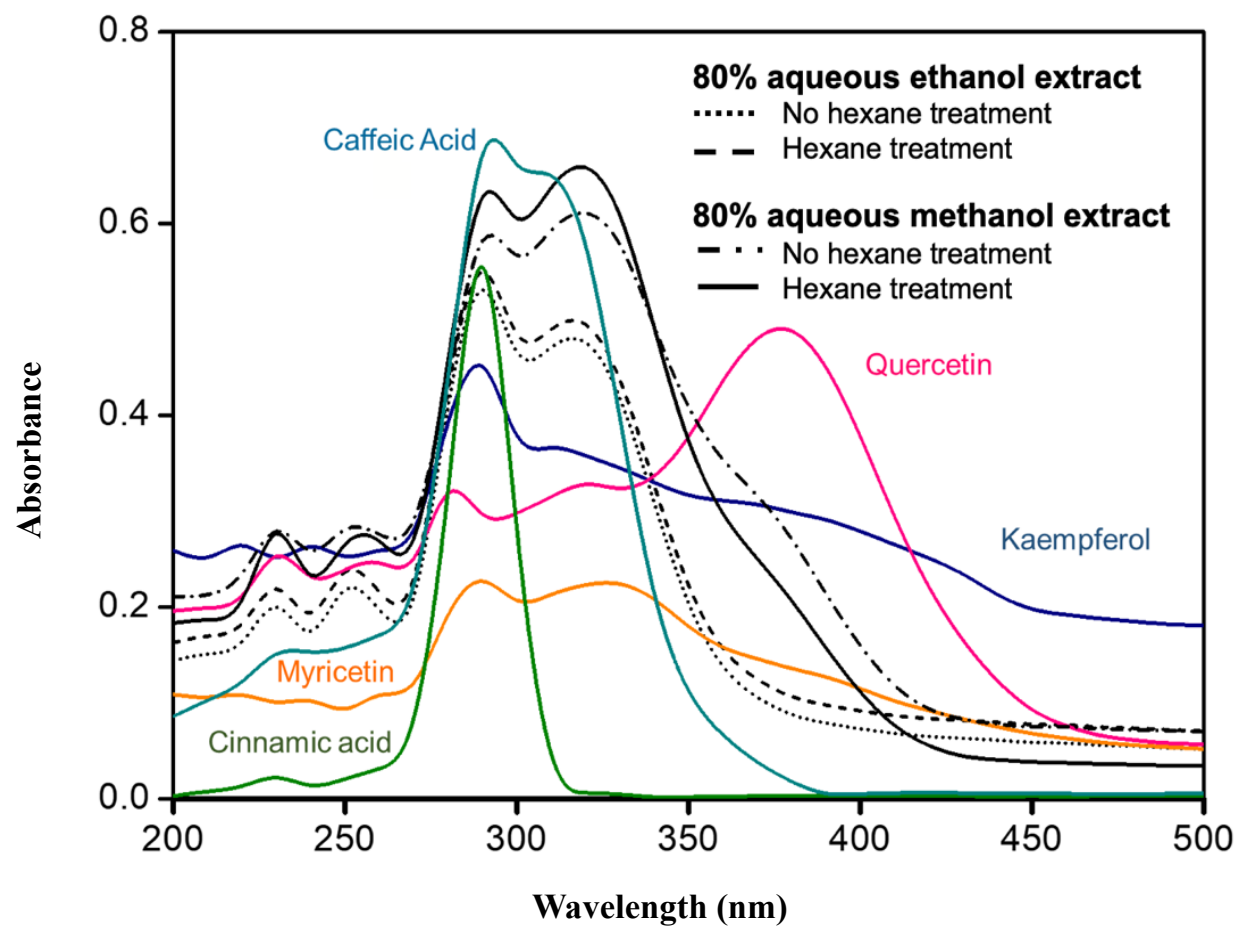

FIGURE 3. UV-Visible spectra of the $80 \%$ aqueous ethanol and methanol extracts of Salvia hispanica L. seeds with and without hexane treatment and standards (myricetin, quercetin, kaempferol, cinnamic and caffeic acid)

Differences were found between the UV-Visible spectra of the aqueous ethanol and methanol extracts, but not between the spectra of their respective ones without and with hexane treatment. The UV-Visible spectra of the
$80 \%$ aqueous ethanol extracts showed peaks at 230, 250, 290, and $320 \mathrm{~nm}$, obtaining the maximum absorbance at $290 \mathrm{~nm}$. This peak is also presented in the spectrums of the kaempferol and the cinnamic acid. In addition, the

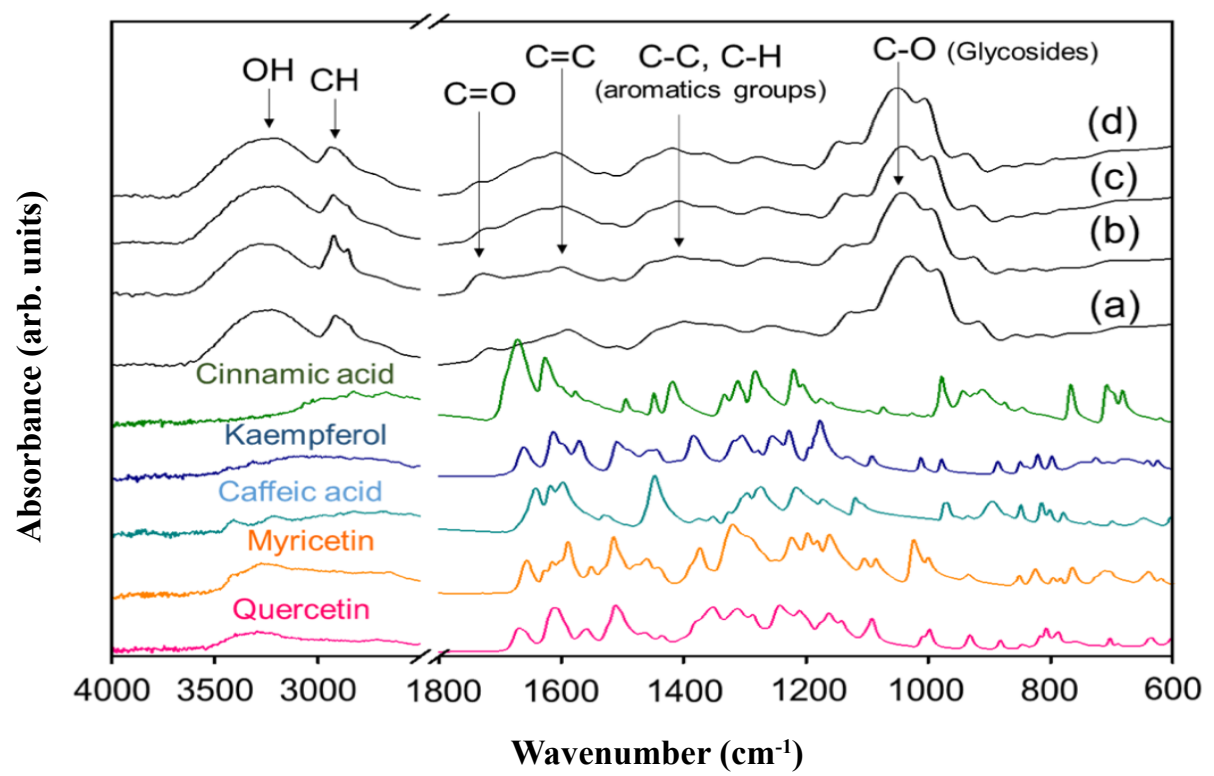

FIGURE 4. FTIR spectra of the $80 \%$ aqueous ethanol extract with hexane treatment (a) $80 \%$ aqueous ethanol extract without hexane treatment (b), $80 \%$ aqueous methanol extract with hexane treatment (c) $80 \%$ aqueous methanol extract without hexane treatment extracts (d) of Salvia hispanica L. seeds and standards (myricetin, quercetin, kaempferol, cinnamic and caffeic acid) 
absorbances of the $80 \%$ aqueous ethanol extracts are similar to the spectrum of caffeic acid. This acid exhibits two main peaks at 290, and $310 \mathrm{~nm}$. In contrast, in the $80 \%$ aqueous methanol extracts the scanning showed absorbance peaks at 230, 250,290, $320 \mathrm{~nm}$ and a broad band at $380 \mathrm{~nm}$. The maximum absorbance peak was at $320 \mathrm{~nm}$. This absorbance profile resembles the spectra of quercetin and myricetin, which could indicate the presence of these types of compounds in the extracts.

The FTIR spectra of the $80 \%$ aqueous ethanol and methanol extracts and the standards are shown in Figure 4. In all the extracts were observed peaks of greater intensity in the spectral interval of $1200-1000 \mathrm{~cm}^{-1}$. These bands correspond to the stretching vibrations of the C-O bond of the structure of glycosides (Silva et al. 2014). The phenolic compounds extracted from plants are not found in free form, they bind to carbohydrates forming structures known as glycosides (Khoddami et al. 2013). These signals are not present in the spectra of the standards.

The signals located between $1408-1598 \mathrm{~cm}^{-1}$ are associated with the stretching vibrations of aromatics groups (Cobaleda et al. 2017). These bands are observed in the extracts of chia and in the standards. At $1725 \mathrm{~cm}^{-1}$ appear the signal of stretching vibration of the carbonyl group. In the standards, this peak appears at $1661 \mathrm{~cm}^{-1}$, in the myricetin, $1658 \mathrm{~cm}^{-1}$, in the kaempferol and 1668 $\mathrm{cm}^{-1}$ in the quercetin. The band at $2920 \mathrm{~cm}^{-1}$ corresponds to the stretching vibration of the $\mathrm{C}-\mathrm{H}$ bond. These bands are observed in the extracts of chia and in the standards. Finally, in the region of $3300-3000 \mathrm{~cm}^{-1}$, the signals corresponding to the $\mathrm{O}-\mathrm{H}$ bonds of the alcohols are observed, which like the aromatic groups, are part of the flavonoid molecule and the phenolic acids. Among the FTIR spectra of the aqueous ethanol and methanol extracts, slight differences were found, but not between their respective with hexane treatments. Confirming as described above, the treatment with hexane does not generate changes in the extracts. The differences observed between the $80 \%$ aqueous methanol and ethanol extracts appear in the region corresponding to the carbonyl group. The spectra of the $80 \%$ aqueous ethanol without treatment have a greater intensity and definition in the peak at $1725 \mathrm{~cm}^{-1}$. These results in conjunction with the variations observed in the UV-Visible spectra may suggest that there are differences in the composition of ethanol and methanol extracts.

\section{CONCLUSION}

The results show that the phenolic compounds in Salvia hispanica L. seeds can be extracted with different ethanol and methanol solutions. The highest total phenolic content was quantified in the $50 \%$ aqueous ethanol and methanol extracts. However, all the extracts have a high DPPH scavenging activity. The $80 \%$ aqueous methanol extracts presented a better antioxidant capacity than the $80 \%$ aqueous ethanol extracts. The UV-Visible and FTIR spectra evidenced that there are differences in the composition of the ethanol and methanol extracts. With exception of the $100 \%$ ethanol extract, the hexane treatment does not influence on the total phenolic content and the DPPH scavenging activity of the extracts. This procedure is not necessary if high purity extracts are not required, so extraction is economized. The profile of the total phenolic content and the antioxidant capacity obtained with different concentrations of ethanol and methanol can serve for choosing the right conditions for the isolation of antioxidants in Chia Seeds according to the application of the extract.

\section{ACKNOWLEDGEMENTS}

We thank the Secretaría de Investigación y Posgrado-IPN for financial support and Consejo Nacional de Ciencia y Tecnología (CONACYT) for the scholarship (236173) to G. Morales-Olán to obtain her PhD degree. All contributed authors declare no potential conflict of interest with respect to authorship, research and/or publication of this paper.

\section{REFERENCES}

Anwar, F., Muhammad, H., Ijaz, A. \& Idbal, S. 2010. Antioxidant activity of $100 \%$ and $80 \%$ methanol extracts from barley seeds (Hordeum vulgare L.): Stabilization of sunflower oil. Grasas y Aceites 61(3): 237-243.

Azmir, J., Zaidul, I.S.M., Rahman, M.M., Sharif, K.M., Mohamed, A., Sahena, F., Jahurul, M. H.A., Ghafoor, K., Norulaini, N.A.N. \& Omar, A.K.M. 2013. Techniques for extraction of bioactive compounds from plant materials: A review. Journal of Food Engineering 117(4): 426-436.

Buddrick, O., Jones, O.A.H., Morrison, P.D. \& Small, D.M. 2013. Heptane as a less toxic option than hexane for the separation of vitamin $\mathrm{E}$ from food products using normal phase HPLC. RSC Advances 3(46): 24063-24068.

Capitani, M.I., Spotorno, V., Nolasco, S.M. \& Tomás, M.C. 2012. Physicochemical and functional characterization of by-products from Chia (Salvia hispanica L.) seeds of Argentina. LWT-Food Science and Technology 45(1): 94-102.

Castañeda-Ovando, A., Pacheco-Hernández, M.L., PáezHernández, M.E., Rodríguez, J.A. \& Galán-Vidal, C.A. 2009. Chemical studies of anthocyanins: A review. Food Chemistry 113(4): 859-871.

Cobaleda, M., Almaraz, N., Alanis, R.E., Uribe, J.N., González, L.S., Muñoz, G., Morán, O. \& Rojas, M. 2017. Rapid determination of phenolics, flavonoids, and antioxidant properties of Physalis ixocarpa Brot. ex Hornem. and 
Physalis angulata L. by infrared spectroscopy and partial least squares. Analytical Letters 51(4): 523-536.

Corona-Jiménez, E., Martínez-Navarrete, N., Ruiz-Espinosa, H. \& Carranza-Concha, J. 2016. Ultrasound-assisted extraction of phenolics compounds from chia (Salvia hispanica L.) seeds and their antioxidant activity. Agrociencia 50(4): 403-412.

Corral-Aguayo, R.D., Yahia, E.M., Carrillo-Lopez, A. \& González-Aguilar, G. 2008. Correlation between some nutritional components and the total antioxidant capacity measured with six different assays in eight horticultural crops. Journal of Agricultural and Food Chemistry 56(22): 10498-10504.

Da Silva, J.K., Batista, Â.G., Betim Cazarin, C.B., Dionísio, A.P., Sousa de Brito, E., Biasoto Marques, A.T. \& Maróstica Junior, M.R. 2017. Functional tea from a Brazilian Berry: Overview of the bioactives compounds. LWT-Food Science and Technology 76(Part B): 292-298.

De Morais, S.M., Cavalcanti, E.S.B., Costa, S.M.O. \& Aguiar, L.A. 2009. Ação antioxidante de chás e condimentos de grande consumo no Brasil. Revista Brasileira de Farmacognosia 19(1): 315-320.

Do, Q.D., Angkawijaya, A.E., Tran-Nguyen, P.L., Huynh, L.H., Soetaredjo, F.E., Ismadji, S. \& Ju, Y.H. 2014. Effect of extraction solvent on total phenol content, total flavonoid content, and antioxidant activity of Limnophila aromatica. Journal of Food and Drug Analysis 22(3): 296-302.

Goli, A.H., Barzegar, M. \& Sahari, M.A. 2004. Antioxidant activity, total phenolic compounds of Pistachio (Pistachia vera) hull extracts. Food Chemistry 92(3): 521-525.

Ignat, I., Volf, I. \& Popa, I. 2011. A critical review of methods for characterization of polyphenolic compounds in fruits and vegetables. Food Chemistry 126(4): 1821-1835.

Ixtaina, V.Y., Nolasco, S.M. \& Tomás, M.C. 2008. Physical properties of chia (Salvia hispanica L.) seeds. Industrial Crops and Products 28(3): 286-293.

Kähkönen, M.P., Hopia, A.I., Vuorela, H.J., Rauha, J.P., Pihlaja, K., Kujala, T.S. \& Heinonen, M. 1999. Antioxidant activity of plant extracts containing phenolic compounds. Journal of Agricultural and Food Chemistry 47(10): 3954-3962.

Khoddami, A., Wilkes, M. \& Roberts, T. 2013. Techniques for analysis of plant phenolic compounds. Molecules 18(2): 2328-2375.

Lim, Y.Y., Lim, T.T. \& Tee, J.J. 2006. Antioxidant properties of guava fruit: Comparison with some local fruits. Sunway Academic Journal 3: 9-20.

MacDonald-Wicks, L.K., Wood, L.G. \& Garg, M.L. 2006. Methodology for the determination of biological antioxidant capacity in vitro: A review. Journal of the Science of Food and Agriculture 86(13): 2046-2056.

Marineli, R., Aguiar Moraes, É., Alves Lenquiste, S., Teixeira Godoy, A., Nogueira Eberlin, M. \& Maróstica, M.R. Jr. 2014. Chemical characterization and antioxidant potential of Chilean Chia seeds and oil (Salvia hispanica L.). LWTFood Science and Technology 59(2): 1304-1310.

Martínez-Cruz, O. \& Paredes-López, O. 2014. Phytochemical profile and nutraceutical potential of chia seeds
(Salvia hispanica L.) by ultra-high performance liquid chromatography. Journal of Chromatography A 1346(13): 43-48.

Miliauskas, G., Venskutonis, P.R. \& Van, T.A. 2004. Screening of radical scavenging activity of some medicinal and aromatic plant extracts. Food Chemistry 85(2): 231-237.

Muñoz, L.A., Cobos, A., Diaz, O. \& Aguilera, J.M. 2012. Chia seeds: Microstructure, mucilage extraction and hydration. Journal of Food Engineering 108(1): 216-224.

Repo-De-Carrasco, R. \& Encina-Zelada, C.R. 2008. Determinación de la capacidad antioxidante y compuestos bioactivos de frutas Nativas Peruanas. Revista de la Sociedad Química del Perú 74(2): 85-89.

Reyes-Caudillo, E. Tecante, A. \& Valdivia-López, M.A. 2008. Dietary fibre content and antioxidant activity of phenolic compounds present in Mexican Chia (Salvia hispanica L.) seeds. Food Chemistry 107(2): 656-663.

Santos, M.C.P. \& Goncalves, É.C.B.A. 2016. Effect of different extracting solvents on antioxidant activity and phenolic compounds of a fruit and vegetable residue flour. Scientia Agropecuaria 7(1): 7-14.

Scapin, G., Schmidt, M.M., Prestes, R.C. \& Rosa, C.S. 2016 Phenolics compounds, flavonoids and antioxidant activity of chia seed extracts (Salvia hispanica) obtained by different extraction conditions. International Food Research Journal 23(6): 2341-2346.

Silva, S.D., Feliciano, R.P., Boas, L.V. \& Bronze, M.R. 2014 Application of FTIR-ATR to moscatel dessert wines for prediction of total phenolic and flavonoid contents and antioxidant capacity. Food Chemistry 150(1): 489-493.

Silveira, M. \& Salas, M. 2014. Chemical characterization of chia (Salvia hispánica L.) for use in food products. Journal of Food and Nutrition Research 2(5): 263-265.

Stalikas, C.D. 2007. Extraction, separation, and detection methods for phenolic acids and flavonoids. Journal of Separation Science 30(18): 3268-3295.

Swain, T. \& Hillis, W.E. 1959. The phenolic constituents of Prunus domestica. I. - The quantitative analysis of phenolic constituents. Journal of the Science of Food and Agriculture 10(1): 63-68

Valdivia, L.A.M. \& Tecante, A. 2015. Chia (Salvia hispanica): A review of Native Mexican seed and its nutritional and functional properties. In Advances in Food and Nutrition Research, edited by Jeyakumar, H. Burlington: Academic Press. pp. 53-75.

Villanueva, A.B., Ferrer, D.A., Civeira, M.E., Gutiérrez, C.I., Laguna, C.M. \& Cerrada, L.E. 2002. Methanol poisoning. Medicina Intensiva 26(5): 264-266.

Yusri, N.M., Chan, K.W., Iqbal, S. \& Ismail, M. 2012. Phenolic content and antioxidant activity of Hibiscus cannabinus L. seed extracts after sequential solvent extraction. Molecules 17(11): 12612-12621.

Zhao, M., Yang, B., Wang, J., Li, B. \& Jiang, Y. 2006. Identification of the major flavonoids from pericarp tissues of lychee fruit in relation to their antioxidant activities. Food Chemistry 98(3): 539-544. 
Centro de Investigación en Biotecnología Aplicada Instituto Politécnico Nacional

Ex-Hacienda de San Juan Molino

Carretera estatal Santa Inés Tecuexcomac-Tepetitla

Km. 1.5, Tepetitla, Tlaxcala. 90700

México
*Corresponding author; email: silvials2004@yahoo.com.mx

Received: 16 May 2019

Accepted: 17 February 2020 